\title{
IDENTIFIKASI JAMUR PATHOGEN PADA AIR BAK TOILET SPBU DI KECAMATAN RUMBAI KOTA PEKANBARU
}

\author{
Mega Pratiwi Irawan ${ }^{1}$, Siti Juariah ${ }^{2}$, Syarifah Rukmaini ${ }^{3}$ \\ ${ }^{1}$ Prodi Analis Kesehatan, FKIK, Universitas Abdurrab Pekanbaru, Indonesia: \\ mega.pratiwi@univrab.ac.id \\ ${ }^{2}$ Prodi Analis Kesehatan, FKIK, Universitas Abdurrab Pekanbaru, Indonesia: \\ sitijuariah@univrab.ac.id \\ ${ }^{3}$ Prodi Analis Kesehatan, FKIK, Universitas Abdurrab Pekanbaru, Indonesia \\ (Korespondensi e-mail: mega.pratiwi@univrab.ac.id)
}

\begin{abstract}
ABSTRAK
Air merupakan salah satu sumber penularan penyakit. Banyak penyakit yang ditularkan melalui air disebabkan oleh kontaminasi bakteri, virus, parasit, dan jamur. Kontaminasi air oleh jamur berasal dari sumber air yang tidak diobati dengan benar. The lacto phenol Cotton Blue (LPCB) solusi bekerja untuk warna jamur ke biru. Tujuan dari penelitian ini adalah untuk mengetahui jamur patogen yang ditemukan di air toilet SPBU di Kabupaten rumbai, kota Pekanbaru. Penelitian ini dilakukan dengan menggunakan metode eksperimental di laboratorium. Tes laboratorium meliputi penanaman pada PDA (Potato dextrose agar) media menggunakan menuangkan pelat. Identifikasi dibuat makroskopis dengan melihat bentuk dan warna koloni, serta mikroskopis menggunakan solusi LPCB. Hasil yang Diperoleh dari studi ini ditemukan di jamur Candida dan ada juga jamur lain seperti Aspergillus, Trichophyton, Penicillium. Air toilet SPBU di Kecamatan rumbai, kota Pekanbaru, menemukan keberadaan jamur patogen.
\end{abstract}

Kata kunci: Air bak, Jamur pathogen, Toilet SPBU

Abstract

Water is a source of disease transmission. Many waterborne diseases are caused by bacterial, viral, parasitic and fungal contamination. Water contamination by fungi comes from water sources that are not treated properly. The Lacto Phenol Cotton Blue (LPCB) solution works to color the fungus to blue. The purpose of this research was to find out pathogenic fungi found in SPBU toilet water in Rumbai Regency, Pekanbaru City. This research was conducted using experimental methods in the laboratory. Laboratory tests include planting on PDA (Potato Dextrose Agar) media using the pour plate method. Identification is made macroscopically by looking at the shape and color of the colony, as well as microscopically using LPCB solution. Results obtained from this study were found in Candida mushrooms and there are also other fungi such as Aspergillus, Trichophyton, Penicillium. SPBU toilet water in Rumbai District in Pekanbaru City found the presence of pathogenic fungi. 


\section{PENDAHULUAN}

Toilet Stasiun Pengisian Bahan Bakar Umum (SPBU) merupakan sarana umum yang disediakan oleh PT. Pertamina yang dapat digunakan oleh masyarakat umum. Banyaknya masyarakat yang menggunakan toilet tersebut, terkadang salah satu diantaranya tidak dapat menjaga kebersihan. Kemudian tidak adanya petugas yang membersihkan toilet dan menguras bak air dapat menyebabkan toilet dan bak air menjadi kotor dan berbau (Sinaga, 2014).

Air merupakan salah satu sumber penularan penyakit, sehingga perlu dilakukan pengawasan terhadap kualitas air. Pengawasan kualitas air bertujuan untuk mencegah penurunan kualitas dan penggunaan air yang dapat mengganggu dan membahayakan kesehatan. Banyak penyakit yang di tularkan melalui air yang di sebabkan dari kontaminasi bakteri, virus, parasit dan jamur (Permenkes, 2017).

Jamur patogen mudah tumbuh pada tempat - tempat yang lembab dan beriklim tropis. Jamur patogen pada umumnya hidup di alam bebas seperti tanah, debris organik dan air, sehingga jamur dengan mudah mengkontaminasi air. Kontaminasi jamur pada air bisa juga berasal dari sumber air yang tidak dijaga dengan baik. Kurangnya pembersihan bak air, jamur dapat tumbuh dan berkembang di dalam air sehingga air tersebut akan menjadi sumber infeksi bagi yang menggunakannya. Perilaku pengguna toilet yang tidak menjaga kebersihan juga dapat berdampak buruk terhadap sanitasi toilet (Prahatamaputra, 2009).

Melihat suatu morfologi dan struktur jamur tidak dapat dilihat oleh mata langsung. Salah satu cara melihat morfologi dan struktur jamur yaitu dengan cara melakukan pewarnaan dengan menggunakan larutan Lacto Phenol Cotton Blue (LPCB). Phenol berfungsi mematikan jamur, lactic acid berfungsi mempertinggi efek penetrasi larutan kedalam hypa, glyserol berfungsi mengawetkan preparat dan mencegah presipitasi cat, cotton blue berfungsi mewarnai jamur menjadi biru (IKAPI, 2015).

Genus jamur seperti Candida albicans menyebabkan keputihan dan gatal pada vagina (Prahatamaputra, 2009), genus Aspergillus yang dapat menyebabkan pneumonia, (Hasanah, 2017), Trichophyton menginfeksi rambut, kulit dan kuku (Irianto, 2013). Penicillium sebagai patogen oportunis yang endemis (Jawets,2010).

Berdasarkan penelitian sebelumnya yang telah dilakukan oleh Indrawati dan Fakhrudin tahun 2016 spesies jamur patogen yang ditemukan adalah Penicillium sp, Trichopyton interdigitae, Geotrichum sp, Trichopyton sp, Microsporum canis, Mycocladus corymbifer. Penelitian Qurohman dan Nugroho 2015 menemukan lima spesies jamur Candida pada air bak toilet wanita di SPBU Surakarta.

Penelitian Suriaman dan Apriliasari
2017 menemukan jamur patogen
Penicillium sp,Fusarium sp, Aspergillus sp,
Microsporum ferrugineum, dan
Microsporum audouinii. Tujuan penelitian
ini adalah untuk mengetahui jamur patogen
yang terdapat pada air bak toilet SPBU di
Kecamatan Rumbai Kota Pekanbaru.

METODE

\section{Jenis Penelitian}

Penelitian ini dilakukan dengan menggunakan metode Experimental laboratory yaitu, suatu metode penelitian dengan melakukan kegiatan percobaan experimen di laboratorium (Notoatmodjo, 2010).

\section{Lokasi dan Waktu Penelitian}

Penelitian ini dilakukan di laboratorium Bakteriologi Prodi DIII Analis Kesehatan Fakultas Kedokteran dan Ilmu Kesehatan Universitas Abdurrab Pekanbaru pada bulan November 2018-Juli 2019.

\section{Populasi dan Sampel}

Populasi pada penelitian ini adalah 13 toilet SPBU di Kecamatan Rumbai Kota Pekanbaru. Sampel yang digunakan adalah 
13 air bak toilet SPBU di Kecamatan Rumbai Kota Pekanbaru.

\section{Pengumpulan Data}

Teknik sampling yang dipilih untuk melakukan penelitian ini adalah total sampling dimana keseluruhan sampel akan dijadikan bahan uji (Notoatmodjo, 2010).

\section{Pengolahan dan Analisis Data}

\section{Prosedur Kerja}

1. Sterilisasi alat gelas. Bungkus alat dengan kertas, masukkan kedalam oven pada suhu 170 0C selama 1 jam.

2. Pengambilan Sampel Air. Sampel air diambil dengan cara mengaduk air terlebih dahulu hingga tercampur rata dengan menggunakan gayung. Air kemudian diambil dan dimasukkan ke dalam botol sampel steril (Indrawati \& Fakhrudin, 2016).

3. Pembuatan Media PDA. Medium Potato Dextrose Agar (PDA) ditimbang sebanyak 19,5 g, kemudian dimasukkan kedalam labu erlemeyer, larutkan dalam 500 $\mathrm{mL}$ akuades, didihkan. Kemudian medium ditutup dengan kapas steril, lalu disterilkan dalam autoklaf selama 15 menit pada suhu $1210 \mathrm{C}$. Setelah proses steril selesai, media dikeluarkan dari autoklaf, didinginkan hingga suhu $45-500 \mathrm{C}$. Setelah itu tambahkan antibiotik kloramfenikol kadar $500 \mathrm{mg}$ sebanyak $5 \mathrm{~mL}$ yang digunakan untuk menghambat pertumbuhan bakteri (Oxoit, 2015).

4. Penanaman kedalam Medium. Pipet sampel air sebanyak $1 \mathrm{~mL}$ masukkan kedalam cawan petri, tambahkan media potato dextrose agar 15-20 $\mathrm{mL}$ kemudian dihomogenisasi dan dilakukan pengulangan sebanyak 3 kali pada setiap sampel (Qurrohman \& Nugroho, 2015). Setelah medium membeku, inkubasi selama $72-96$ jam. Penanaman sampel pada medium harus dikerjakan secara aseptis agar tidak terjadi kontaminasi (Indrawati \& Fakhrudin, 2016).

5. Jaminan kualitas sample. Jaminan kualitas sampel dilakukan supaya menjamin tidak ada kontaminasi yang berasal dari luar dengan kontrol negatif. Kontrol negatif merupakan media PDA yang tidak digunakan inokulasi sampel air, namun juga diperlakukan seperti media dengan sampel. Kontrol ini digunakan untuk menjamin bahwa sampel tidak terkontaminasi saat melakukan percobaan (Qurrohman \& Nugroho, 2015).

6. Identifikasi Jamur. Ambil larutan Lacto Phenol Cotton Blue (LPCB) dan letakkan pada objek glass. Ambil koloni jamur dengan menggunakan ose kemudian campurkan dengan larutan Lacto Phenol Cotton Blue. Setelah itu, tutup dengan deck glass periksa dibawah mikroskop (IKAPI, 2015).

Analisis data dilakukan dengan cara mengamati data hasil pengamatan secara deskriptif. Setelah dilakukan identifikasi, dilanjutkan dengan melakukan perbandingan antara hasil yang terlihat dibawah mikroskop dengan atlas Parasitologi kedokteran.

\section{HASIL}

Telah dilakukan Identifikasi jamur patogen pada air bak toilet SPBU di Kecamatan Rumbai Kota Pekanbaru pada 18 Juni 2019, dan di peroleh dari 13 sampel dari 5 SPBU di Kecamatan Rumbai Kota Pekanbaru maka didapatkan hasil sebagai berikut: 
Tabel 1. Hasil Identifikasi Jamur Patogen pada Air Bak Toilet SPBU Kota Pekanbaru

\begin{tabular}{|c|c|c|c|}
\hline No & Lokasi & $\begin{array}{l}\text { Kode } \\
\text { Sampel }\end{array}$ & Karakteristik \\
\hline \multirow[t]{4}{*}{1} & \multirow[t]{4}{*}{ SPBU 14282674} & $1 \mathrm{a}$ & $\begin{array}{l}\text { 1. Bentuk oval, Koloni bulat berwarna krem, berbau ragi } \\
\text { 2. Hifa berwarna putih, tekstur seperti kapas }\end{array}$ \\
\hline & & $1 \mathrm{~b}$ & 1. Hifa berwarna putih, tekstur seperti kapas \\
\hline & & $1 \mathrm{c}$ & 1. Bentuk oval, Koloni bulat berwarna krem, berbau ragi \\
\hline & & $2 a$ & 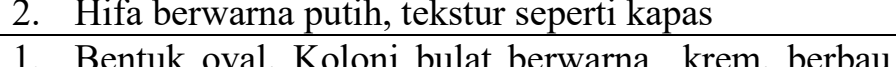 \\
\hline \multirow{4}{*}{2} & \multirow{4}{*}{ SPBU 142826114} & $2 \mathrm{a}$ & $\begin{array}{l}\text { 1. Bentuk oval, Koloni bulat berwarna Krem, berbau } \\
\text { ragi }\end{array}$ \\
\hline & & & 2. Hifa berwarna putih, tekstur seperti kapas \\
\hline & & & 3. Koloni berwarna hijau dan pinggiran berwarna putih \\
\hline & & & $\begin{array}{l}\text { 4. Tengah koloni berwarna hijau dan pinggir berwarna } \\
\text { putih }\end{array}$ \\
\hline \multirow[t]{5}{*}{3} & \multirow[t]{5}{*}{ SPBU 14282686} & $3 a$ & 1. Hifa berwarna putih, tekstur seperti kapas \\
\hline & & $3 b$ & 1. Bentuk oval, Koloni bulat berwarna krem, berbau ragi \\
\hline & & $3 \mathrm{c}$ & 1. Bentuk oval, Koloni bulat berwarna krem, berbau ragi \\
\hline & & & 2. Koloni berwarna hijau dan pinggiran berwarna putih \\
\hline & & $3 d$ & $\begin{array}{l}\text { 3. Bentuk oval, Koloni bulat, berwarna krem, berbau } \\
\text { ragi }\end{array}$ \\
\hline \multirow{5}{*}{4} & \multirow{5}{*}{ SPBU 14282610} & $4 \mathrm{a}$ & $\begin{array}{l}\text { 1. Bentuk oval, Koloni bulat berwarna krem, berbau } \\
\text { ragi }\end{array}$ \\
\hline & & & $\begin{array}{l}\text { 2. Koloni berwarna hitam dengan pinggiran berwarna } \\
\text { putih }\end{array}$ \\
\hline & & $4 \mathrm{~b}$ & $\begin{array}{l}\text { 1. Koloni berwarna hitam dengan pinggiran berwarna } \\
\text { putih }\end{array}$ \\
\hline & & $4 \mathrm{c}$ & 2. Bentuk oval, Koloni bulat berwarna krem, berbau ragi \\
\hline & & & $\begin{array}{l}\text { 3. Koloniberwarna hitam dengan pinggiran berwarna } \\
\text { putih }\end{array}$ \\
\hline \multirow{4}{*}{5} & \multirow{4}{*}{ SPBU 14281616} & $5 \mathrm{a}$ & 1. Bentuk oval, Koloni bulat berwarna krem, berbau ragi \\
\hline & & & 2. Koloni berwarna hijau dan pinggiran berwarna putih \\
\hline & & & 3. Hifa berwarna putih, tekstur seperti kapas \\
\hline & & $5 b$ & 1. Bentuk oval, koloni bulat berwarna krem, berbau ragi \\
\hline
\end{tabular}

Berdasarkan Tabel 1 diatas pada sampel air bak SPBU 14282674 yang telah diteliti di temukan jamur Candida, Trichopyton, pada sampel SPBU 142826114 ditemukan jamur Candida, Trichopyton, Aspergillus, Penicillium, pada sampel SPBU 14282686 ditemukan jamur Trichopyton, Aspergillus, Candida, pada sampel SPBU 14282610 ditemukan jamur Candida, Aspergillus, pada sampel SPBU 14281616 ditemukan jamur Candida, Aspergillus, Trichophyton. 
Tabel 2. Hasil Pemeriksaan Makroskopis dan Mikroskopis Jamur Patogen

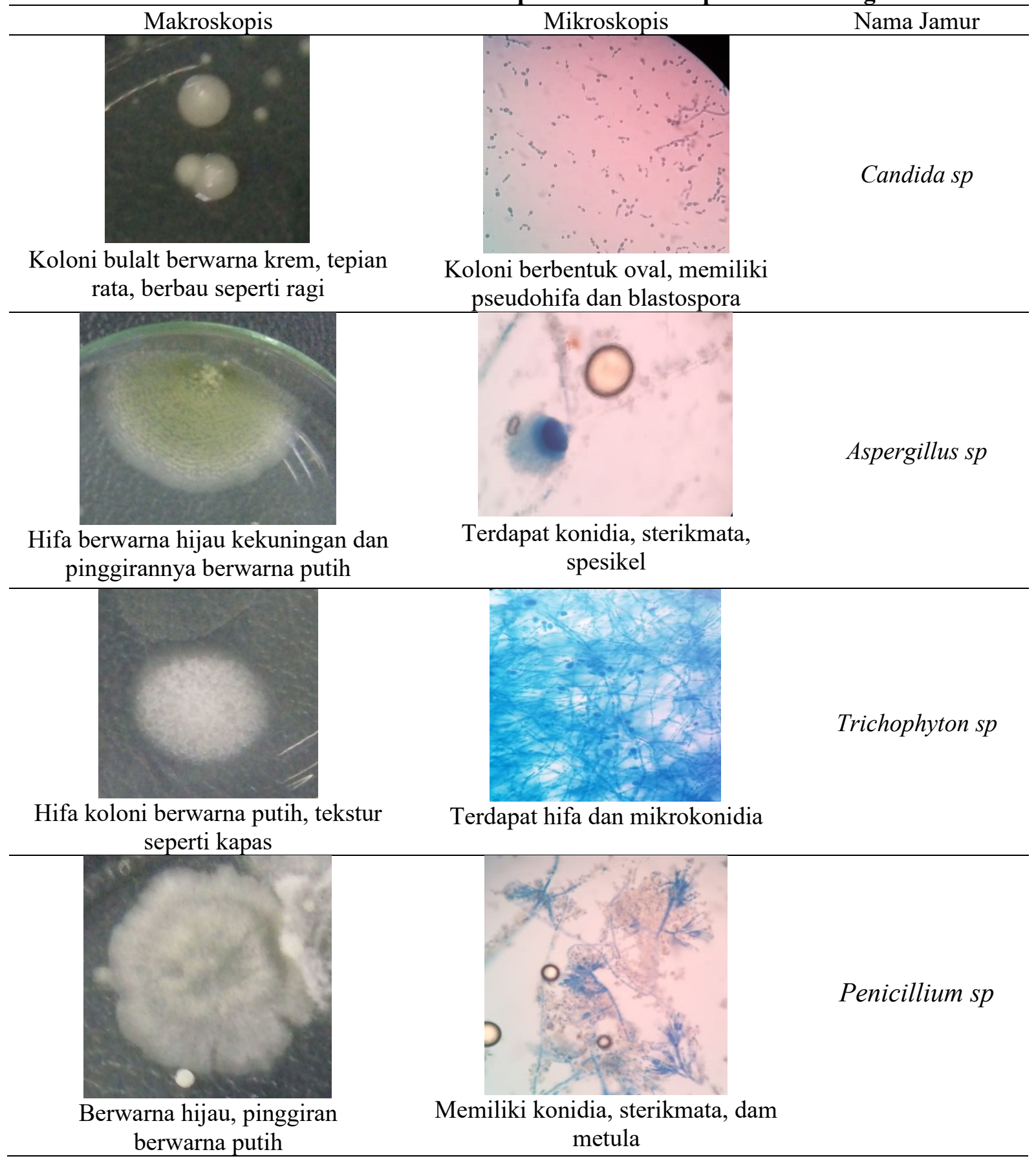

Dari hasil penelitian di atas diketahui bahwa pada air bak toilet SPBU di Kecamatan Rumbai Kota Pekanbaru di temukan adanya jamur patogen. Jamur patogen yang ditemukan pada penelitian ini adalah Candida, Aspergillus, Trichophyton dan Penicillium. Adanya jamur patogen tersebut dikarenakan jamur berada di tempat-tempat yang lembab dan berada di udara bebas, sehingga air bak toilet tersebut mudah terkontaminasi oleh jamur.

\section{PEMBAHASAN}

Hipotesis utama tentang komposisi kumpulan mikroba di lingkungan dalam ruangan adalah bahwa kumpulan jamur 
disusun oleh udara luar dengan kontribusi sedang oleh pertumbuhan permukaan, sedangkan kumpulan bakteri dalam ruangan mewakili campuran bakteri yang masuk dari udara luar, gudang oleh penghuni gedung, dan tumbuh di permukaan. Beberapa pertumbuhan jamur endogen pada permukaan rumah tangga dan toilet umum, memang sering terjadi, terutama pada saluran air dan kulit, semua permukaan tempat tinggal muncul - sampai tingkat yang berbeda - menjadi pengumpul pasif jamur udara asal putatif luar, termasuk pada air, dapat terkontaminasi dengan jamur (Adams, Miletto, Taylor, \& Bruns, 2013).

Studi jamur terutama berfokus pada spora, sel-sel ragi, dan fragmen propagul dan hifa, kumpulan jamur di udara yang dikumpulkan dari debu yang menetap secara pasif tidak berbeda antara ruangan seperti dapur, kamar mandi, kamar tidur, dan ruang tamu. keberadaan, kolonisasi dan pertumbuhan jamur dalam air keran tergantung pada beberapa faktor, seperti lokasi sumber air primer, penyinaran matahari, suhu, komposisi ion dan $\mathrm{pH}$, keberadaan bahan organik, konsentrasi oksigen terlarut, pengolahan air, penggunaan bahan untuk sistem distribusi air menyebabkan kemungkinan pembentukan biofilm (De Toni \& Reilly, 2011; Novak Babič et al., 2017).

Sejalan dengan standar kebersihan yang lebih tinggi dan masalah ekologis, penggunaan suhu air yang rendah menyebabkan spesies mikroba yang toleran terhadap stres, mampu membentuk biofilm dan mendegradasi bahan baru, jamur menunjukkan kemampuan beradaptasi yang luar biasa terhadap perubahan kondisi kehidupan dan menjadi terdeteksi secara teratur di lingkungan yang padat terkait dengan populasi dengan kepadatan lebih tinggi, bahan buatan manusia, dan senyawa kimia kompleks. Karena kemampuan beradaptasi yang tinggi pada tingkat fisiologis, jamur dapat menjajah lingkungan dengan kondisi pertumbuhan ekstrim, salah satunya adalah sistem air oligotrofik.
Kehadiran jamur dalam sumber air diselidiki didukung dengan keberadaan ion tertentu, perubahan $\mathrm{pH}$, suhu, sinar matahari dan bahan organik (Pedro-Botet et al., 2007; Zalar, Novak, De Hoog, \& Gunde-Cimerman, 2011; Zupančič, Babič, Zalar, \& Gunde-Cimerman, 2016).

Jamur ada di mana-mana baik di dalam maupun di luar ruangan, paparan mereka menyebabkan alergi, infeksi dan kondisi kesehatan yang merugikan lainnya. Daam sebuah penelitian, penilaian jamur dalam ruangan lazim di enam toilet (toilet laboratorium Bioteknologi $1 \& 2$, toilet laboratorium Mikrobiologi $1 \& 2$ dan toilet laboratorium Biologi 1 \& 2) di Presco Campus, Ebonyi State University Abakaliki, Hasilnya mengungkapkan delapan spesies jamur; Aspergillus, Trichosporonoides, Gibellula, Beauvaria, Stachybotrys, Illosporium, Botrytis dan Rhizoctonia. Aspergillus spp adalah yang paling dominan di semua toilet dengan tingkat prevalensi $75 \%$, kemudian Aspergillus adalah Gibellula dan Illosporium. Pada toilet laboratorium mikrobiologi, hanya memiliki Aspergillus dan juga jamur terendah yang berhubungan dengan seringnya mencuci (Ezikanyi, Nnamani, \& Inyang).

Dalam penelitian ini didapatkan beberapa jamur yang ada di toilet, salah satunya adalah jamur Candida merupakan jamur patogen sistemik yang merupakan flora normal pada kulit. Karakteristik jamur Candida yang terlihat secara makroskopis adalah koloni berbetuk bulat, berwarna krem, berbau seperti ragi, dan secara mikroskopis koloni berbetuk oval. Sama seperti teori yang dikemukakan oleh Jawetz (2010), jamur Candida tersebar luar di lingkungan, organisme ini merupakan flora normal pada kulit, membran mukosa, dan saluran pencernaan.

Karakteristik jamur Candida $\mathrm{sp}$ seperti sel ragi tunas, berbentuk oval, berukuran 3-6 $\mu \mathrm{m}$, pada media PDA Candida menghasilkan koloni bulat 
berwarna krem dan berbau seperti ragi. Candida sp juga membentuk pseudohifa, pseudohifa pada medium tumbuh dibawah permukaan agar. Beberapa spesies Candida mampu menyebabkan Kandidiasis. Kandidiasis merupakan mikosis sistemik, dan jamur yang paling sering dijumpai adalah Candida albicans, candida tropicalis, Candida parapsilosis, Candida glabrata, Candida guilliermondii, Candida dubliniensi.

Menurut Prahatamaputra (2009) Adanya kandungan jamur Candida pada air bak toilet dikarenakan jumlah pengguna toilet rata-rata perhari, frekuensi membersihkan toilet, Derajat Keasaman $\mathrm{pH}$ air bak toilet tersebut. Selain itu, air yang tergenang pada bak toilet mengandung 80 $\%$ jamur Candida. Air yang mengandung Candida dapat menyebabkan keputihan dan rasa gatal pada vagina.

Pada penelitian ini jamur Penicillium hanya ditemukan pada satu tempat adanya jamur Penicillium dikarenakan tempat sampel tersebut terlihat sangat kotor dan berbau dan terlihat banyak kotoran lain yang terlihat pada tempat tersebut dan spesies Penicillium yang bersifat patogen hanya ada satu (Penicillium marneffei).

Menurut Irianto (2013), jamur Penicillium merupakan jamur dimorfik yang biasanya tidak patogen, kecuali Penicillium marneffei. Pada medium biasanya ditandai dengan koloni mula-mula berwarna putih dan semakin lama berubah menjadi warna kehijauan. Adanya jamur Penicillium pada air bak dikarenakan jamur membutuhkan air dan udara yang lembab sehingga, jamur tidak dapat tumbuh apa bila tidak ada air. Pada mikroskop hifa tampak bersepta,conodiophore bercabang, diatas metula terdapat phialide yang menghasilkan konidia.

Menurut Subandi (2014), Penisiliosis adalah penyakit yang disebabkan oleh Penicillium marneffei yang endemis didapatkan di Asia Tenggara dan Cina Selatan. Gejalanya adalah penurunan berat badan yang dratis, demam, malaise, dan limfa denopati. Risiko infeksi utama yang dapat menyebabkan penisilosis adalah imuno defisiensi akibat HIV, AIDS, tuberculosis. Penicillium marneffei membentuk sel menyerupai ragi yang ditengahnya terdapat septum. Pada kultur jamur Penicillium marneffei terlihat berwarna kehijauan atau keabu-abuan yang menghasilkan konidiospora dengan pigmen kemerahan.

Jamur Aspergillus adalah jamur yang terdapat di mana-mana sehingga jamur tersebut mudah tumbuh, dan spora dari jamur tersebut menempel pada bak atau menempel pada keran air dan apabila bak air tidak dibersihkan secara rutin spora jamur yang menempel akan berkembang biak di dalam bak toilet tersebut. Menurut teori Jawetz (2006), Aspergillus adalah jamur safrofit yang terdapat di mana-mana di alam, dan aspergillosis terdapat diseluruh dunia. Aspergillus sp tumbuh secara cepat, menghasilkan hifa dengan ciri struktur konidia yang khas. Jamur Aspergillus ini menghasilkan banyak konidia kecil yang mudah di aerosol. Setelah manusia terhidup konidiofor orang yang atopik sering mengalami reaksi alergi berat terhadap antigen konidia. Karakteristik jamur aspergillus pada penelitian ini adalah jamur Aspergillus niger koloni pada bagian tengah berwarna hitam dan pada bagian pinggirnya berwarna putih dan Aspergillus flavus warna koloni hijau dan bagian tepi koloni berwarna putih.

Jamur Trichophyton merupakan
dermatofita yang hidup di tanah,
berdasarkan tempat hidupnya jamur
tersebut dapan mengkontaminasi air
sehingga manusia yang terinfeksi dapat
terkena kutu air dan infeksi pada kuku.

Pada media PDA koloni jamur Trichophyton terlihat hifa berwarna putih dan teksturnya seperti kapas, pada mikroskop terlihat adanya hifa dan mikrokonidia. Menurut Soedarto (2015), genus Trichophyton mempunyai sejumlah 
spesies penting yang dapat menyebabkan penyakit dermatofitosis pada hewan dan manusia.

Beberapa penelitian, ditemukan berbagai macam jenis jamur/fungi dalam saluran air, di dominasi jamur Fusarium, Penicillium dan Mucor, terutama (dapur, wastafel kamar mandi, bathtub). diperkirakan mycobiota pada kulit dahi oleh Malassezia, yang dapat menjadi penyebab ketombe, juga beberapa jamur lain seperti Candida dan Aspergillus, dan beberapa keberadaan jamur permukaan (Adams et al., 2013; Short, O'Donnell, Zhang, Juba, \& Geiser, 2011; Zhang et al., 2011).

Berdasarkan pada pemeriksaan mikroskopis langsung Trichophyton dapat dibagi menjadi dua kelompok yaitu: Kelompok yang membentuk mikrokonidia yaitu Trichophyton eqiunum, Trichophyton erinacei, Trichophyton schoenleinii, dan Trichophyton soudanense. Kelompok yang tidak membentuk konidia yaitu Trichophyton verrucosum, Trichophyton violaceum, Trichophyton concentricum, Trichophyton schoenleinii, dan Trichophrton soudanense. Genus Trichophyton ditandai dengan perkembangan dari kedua dinding halus makrokonidia dan mikrokonidia. Makrokonidia berbentuk lateral pada hifa atau pada pedikel pendek, dan memiliki dinding tipis atau tebal, halus dan berukuran 4-6 x 8-50 mm. Mikrokonidia berbentuk bulat atau tidak beraturan dengan ukuran 23 x 2-4 mm, dengan adanya mikrokonidia dapat membedakan genus Epidermophyton.

\section{KESIMPULAN DAN SARAN}

Setelah dilakukan penelitian tentang Identifikasi jamur patogen pada air bak toilet SPBU di Kecamatan Rumbai Kota Pekanbaru maka dapat disimpulkan, dari 13 sampel air bak toilet SPBU di Kecamatan Rumbai Kota Pekanbaru ditemukan adanya jamur patogen (Aspergillus, Trichophyton, Candida, Penicillium).

\section{DAFTAR PUSTAKA}

Adams, R. I., Miletto, M., Taylor, J. W., \& Bruns, T. D. (2013). The diversity and distribution of fungi on residential surfaces. PLoS ONE, 8(11).

De Toni, P. S.-A., \& Reilly, K. (2011). A REVIEW OF FUNGI IN DRINKING WATER AND THE IMPLICATIONS FOR HUMAN HEALTH.

Ezikanyi, D. N., Nnamani, C. V., \& Inyang, U. J. Assessment of Airborne Fungi in an Indoors Laboratory Toilet.

Hasanah, U. 2017. Mengenal Aspergillosis, Infeksi Jamur Genus Aspergillus. Jurnal Keluarga Sehat Sejahtera, 15(30), 76-86.

Indrawati, I., dan Fakhrudin, S. D. 2016. Isolasi dan Identifikasi Jamur Patogen pada Air Sumur dan Air Sungai di Pemukiman Warga Desa Karangwangi, Cianjur, Jawa Barat. Jurnal Biodjati, 1(1), 27-38.

IKAPI. 2015. Pemeriksaan Mikrobiologi pada Penyakit Infeksi. Sagung Seto. Surabaya.

Irianto, K. 2013. Parasitologi Medis. Alfabeta. Bandung.

Jawets, A.,mMelnick, J., dan adelberg, A. 1995. Mikrobiologi Kedokteran. EGC Jakarta.

Jawets, A.,mMelnick, J., dan adelberg, A. 2004. Mikrobiologi Kedokteran. EGC Jakarta.

Jawets, A.,mMelnick, J., dan adelberg, A. 2006. Mikrobiologi Kedokteran. EGC Jakarta.

Jawets, A.,mMelnick, J., dan adelberg, A. 2010. Mikrobiologi Kedokteran. EGC Jakarta.

Novak Babič, M., Gunde-Cimerman, N., Vargha, M., Tischner, Z., Magyar, D., Veríssimo, C., . . . Brandão, J. (2017). Fungal Contaminants in Drinking Water Regulation? A Tale of Ecology, Exposure, Purification and Clinical Relevance. International journal of environmental research and public health, $14(6), \quad 636$. doi:10.3390/ijerph14060636.

Notoatmodjo, S. 2010. Metodologi Penelitian Kesehatan. RINEKA CIPTA.Jakarta.

Pedro-Botet, M. L., Sanchez, I., Sabria, M., Sopena, N., Mateu, L., García-Núñez, M., \& Joly, C. R. (2007). Impact of 
copper and silver ionization on fungal colonization of the water supply in health care centers: implications for immunocompromised patients. Clinical infectious diseases, 45(1), 84-86.

Prahatamaputra, A. 2009. Karakteristik Jamur Candida albicans Berbasis Fermentasi Karbohidrat Pada Air Bak WC Sekolah Menengah di Kelurahan Alalak Utara. Jurnal Wahana-Bio, 2(2).

Qurrohman, M. T., dan Nugroho, R. W. 2015. Pengaruh Frekuensi Menguras Terhadap Jumlah Candida sp. Pada Air Bak Toilet Wanita di SPBU Surakarta. Biogenesis, 3(1).

Soedarto. 2015. Mikrobiologi Kedokteran. Sagung Seto. Surabaya.

Sinaga, A. Y. (2014). Sanitasi dan Pemantauan Jentik Nyamuk pada Toilet Sekolah Dasar di Desa Sei Rotan Kecamatan Percut Sei Tuan Kabupaten Deli Serdang Tahun 2013. Lingkungan Dan Keselamatan Kerja, 3(2).

Subandi. 2014. Mikrobiologi. PT Remaja Rosdakarya. Bandung.

Suriaman, E., dan Apriliasari, W. P. 2017. Uji Mpn Coliform dan Identifikasi Fungi Patogen pada Air Kolam Renang di Kota Malang. Jurnal SainHealth, 1(1), $15-22$.

Short, D. P., O'Donnell, K., Zhang, N., Juba, J. H., \& Geiser, D. M. (2011). Widespread occurrence of diverse human pathogenic types of the fungus Fusarium detected in plumbing drains. Journal of Clinical Microbiology, 49(12), 4264-4272.

Zalar, P., Novak, M., De Hoog, G., \& GundeCimerman, N. (2011). Dishwashers-a man-made ecological niche accommodating human opportunistic fungal pathogens. Fungal biology, 115(10), 997-1007.

Zhang, E., Tanaka, T., Tajima, M., Tsuboi, R., Nishikawa, A., \& Sugita, T. (2011). Characterization of the skin fungal microbiota in patients with atopic dermatitis and in healthy subjects. Microbiology and immunology, 55(9), 625-632.

Zupančič, J., Babič, M. N., Zalar, P., \& GundeCimerman, N. (2016). The black yeast Exophiala dermatitidis and other selected opportunistic human fungal pathogens spread from dishwashers to kitchens. PLoS ONE, 11(2).

\section{INFORMASI TAMBAHAN}

\section{Lisensi}

Hakcipta (c) 2019 Health Information : Jurnal Penelitian

artikel akses terbuka ini dapat disebarkan seluas-luasnya sesuai aturan Creative Commons Attribution-ShareAlike 4.0 International License dengan catatan tetap menyebutkan penulis dan penerbit sebagaimana mestinya.

Catatan Penerbit: Poltekkes Kemenkes Kendari menyatakan tetap netral sehubungan dengan klaim dari perspektif atau buah pikiran yang diterbitkan dan dari afiliasi institusional manapun. 